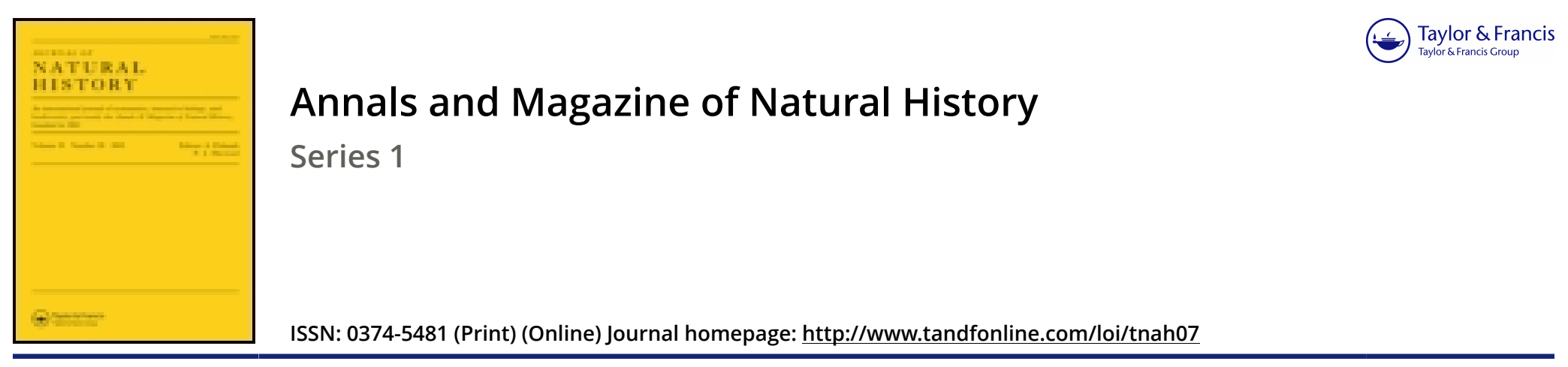

\title{
XLV.-Notices of Fungi in the Herbarium of the British Museum
}

\section{Rev. M. J. Berkeley M.A., F.L.S.}

To cite this article: Rev. M. J. Berkeley M.A., F.L.S. (1843) XLV.-Notices of Fungi in the Herbarium of the British Museum, Annals and Magazine of Natural History, 10:sup66, 369-385, DOI: $10.1080 / 03745484309445244$

To link to this article: http://dx.doi.org/10.1080/03745484309445244

册 Published online: 04 Dec 2009.

Submit your article to this journal $\sqsubset \pi$

Џlll Article views: 1

Q View related articles 두 


\section{THE ANNALS}

\section{AXD \\ MAGAZINE OF NATURAL HISTORY.}

SUPPLEMENT TO YOL. X. JANUARY 1843.

XLV.-Notices of Fungi in the Herbarium of the British Museum. By the Rev. M. J. Berkelex, M.A., F.L.S.

[W'ith Four Plates.]

'THE greater part of the Fungi described in the present memoir were collected by König in Ceylon, a country which has hitherto made very slight contributions to mycology. 'They consist principally of Polypori, which, with the exception of one or two cosmopolites, are new. König had evidently in most cases rell distinguished the species, and probably intended to publish them. As most of them lave manuscript names, I have thought it incumbent upon me to preserve them where it was possible, though obliged to alter the generic name. The other Fungi are mostly those described by Swartz in his 'Flora India Occidentalis.' Of several of these I have giren figures, which will I trust be acceptable as clearing up difficultics and illustrating some very interesting and singular productions. I trust that one cffect of my Iabours may be to draw attention to a portion of our national herbarium, which, though containing scveral objects of interest, is perhaps that which has hitherto received the ferest contributions.

As regrads the species themsclves, it is very possible, thourh I have had access to a large portion of the described species of exotic Fungi, that I may have failed to recognise some alleady published. If so, it will at any rate be in the power of any competent person to correct the errol's I may have made by an inspection of the individual specimens described. I cannot close these observations without making due acknowledgement to $\mathrm{D}_{\mathrm{r}}$. Brown and Mr. Bennett for the free and continued access which they kindly gave me to this portion of the herbarium.

1. Lentinus fulvus, n s. Pileo profunde infundibuliformi sulcato-striato subzonato badio; tomento brevi fasciculato fulvo subhispido versus marginem densiori vestito, inmixtis sctis longioribus rectis ; lamellis cinercis distantibus integerrimis onnibus una desinentibus; stipite hispido-tomentoso subacquali.

In Herb. Mus. Brit., without habitat. Ann.\&.Mag. N. Hist. Vol.x. Suplul. 
Pileus $1 \frac{3}{4}$ of an inch broad, deeply infundibuliform, regularly striato-sulcate from within a short distance of the obscurcly-zoned dark-bay centre, clothed with short fasciculate, tawny, somewhat hispid dorn, which is denser towards the margin and mixed with long straight browner setx; margin arched. Gills cinereous brown, distant, ending ncarly at the same point, but slightly decurrent, their edrge quite entire. Stem $1 \frac{1}{2}$ inch high, 2 lines thick at the base, nearly equal, clothed with hispid down unmixed with setie, which extends for some distance up the gills, making a dark band at their base.

There is a slight resemblance between this well-marked spécies and Lentimus strigosus, but its closest ally is Lentinus fasciatus.

PLate IX. fig. 1. Lentinus fultus, nat. size.

2. Lentinus crinitus, Fr. Pilco infundibuliformi pilosotomentoso stipiteque tenerrime subglabro levi subochraceis; lamellis aqualibus denticulatis pallidioribus. Ag. crinitus, J. Sp. Pl. cd. 2. p. 164.1. Pocillaria lanuginosa, \&c., Brown's Hist. Jam. tab. 15. fig. 1.

Jamaica, Swartz. Herb. Mus. Brit.

Pilcus $\frac{3}{4}$ of an inch broad, decply infundibuliform, pale ochraccous, clothed with somewhat curled, soft, pale, tawny, subfasciculate hairs; margin deflexed. Gills palc, very narrow, all ending at the same point, their edge denticulate, with shallow notches. Stem about 1 inch high, about 1 line thick, sprinkled with little downy patches, beneath which it is pale and silky.

Described from a specimen in the British Museum, marked by Swartz. The synonym of Plumier quoted by Linnæeus and Fries is evidently something very different.

PLate IX. fig. 2. Lentinus crinitus, nat. size.

3. Lentinus connatus, Berk. in Lond. Journ. of Bot. $=" P e-$ ziza Agaricina, Fl. Zeyl.," König in Herb. Mus. Brit.

4. Panus arcolatus, n. s. Pileis imbricatis suborbicularibus undulatis glabris arcolatis lateritio-fulvis ; lamellis paucis latis rigidis lateritio-cinereis.

In IIerb. Mus. Brit., without habitat. On charred wood.

Pilei I inch broad, scarcely so much long ; stemless, suborbicular, subplicate, imbricated, arcolate, smooth; but the areole are minutely cracked, so as to present a pruinose appearance, tawny, with a shade of brick-red. Gills few, very broad, rigid, cincreous, with a sublateritious tinge, not at all dichotomous; edge entire.

Piate.IX. fig. 3. Panus areolahus, mat. size. 
5. Xerotus Berterii, Mont.! (non X. Bertierii) $={ }^{" P}$ Pez. nervosa concava hemispharica atropurpurca; habitat in densissimis sylvis Malacce.” König in Herb. Mus. Brit.

Dr. Montagne remarks to me in a letter lately received, speaking of Lentinus Berterii, that Fries has unfortunately changed the name Berterii into Bertierii. He writes that this is the more important, as there is a French surgeon at Bourbon named Bertier who is a mycologist.

6. Schizophyllum commune, Fr. = Ay. radiatus, Sw.! Prodr. p. 148.

7. Lenzites striata, $\mathrm{Fr} .=$ Ag. striatus, Sw.! Prod. p. 148 ; Fl. Ind. Occ. p. 1920.

This species appears to be common in Guiana from the quantity of specimens brought by Dr. Schomburgk. The name is calculated to mislead, as the pileus is in fact scarcely at all striate. Swartz's specific name probably referred to the obsolete zones. This and another nearly allied species from Guiana resemble much Lenzites abietina. I shall hope to describe both in an account of the Fungi collected by Schomburgk which are now in the herbarium of Sir W. J. Hooker.

8. Pol.Agariccus (König sub Bolcto). P'ileo c lento coriacco convexo umbilicato azono glaberrimo; margine involuto demum subnudo; stipite centrali subelongato flexuoso dcorsum velutino ; poris submagnis subhexagonis decurrentibus. "Bol. agariceus, Fl. Zeyl. in nemorosis," Kön. in Herb. Mus. Brit.

Ceylon, König. IIerb. Mus. Brit.

Pilcus 1 inch broad, quite smooth, convex, umbilicated; margin more or less involute, obscurely ciliated. Stem $1 \frac{1}{4}-$ $1 \frac{1}{2}$ inch long, $\frac{1}{2}-1$ line thick, flexuous, rather thickened above, where it is nearly smooth, velvety below. Pores radiating, subhexagonal, elongated, $\frac{1}{5} \frac{1}{6}$ th of an inch broad, decurrent; dissepiments thin, acute.

Allied to Pol.arcularius and P. tricholoma, but abundantly distinct. In an carly stage of growth the cilia are probably more visible.

9. Polyporus sacer, Fr. Pileo tenui rigidiusculo orbiculari profunde umbilicato zonato, fusco rufoque variegato glabrescente, radiatim striato. Stipite centrali radicato fulvo-brunneo, sursum attcnuato velutino; hymenio pallido a stipite omnino distincto; poris mediis subhexagonis.

IIerb. Mus. Brit., without habitat.

Pileus 4 inches across, rather decply umbilicate, thin, but rather rigid, orbicular, beautifully zoned, and variegated with shades of deep brown and red; at first minutely velvety, marked in a radiating direction with strie. Stem 6 inches high, about half in inch thick, hard, white within, attenuated 2 B 2 
upwards, and then expanding; below incrassated, flexuous, and rooting deeply, coated with a dull tawny brown crust, which, especially near the pileus, is permanently though minutely velvety. Hymenium pale, ending abruptly both towards the margin and stem; margin brown, quite barren; pores rather long, $\frac{1}{6}$ th of an inch broad, subhexagonal, rather regular; sulistance white, corky, but silky.

This very splendid species appears clearly to be the same with what Fries has described from Guinea, where it is said to be an object of superstition with the ncgroes. As the figure to which he refers is unpublished, the present sketch will not be superfluous. Only a single shect in the form of an academic dissertation has appeared of the description of Afzelius' Fungi. 'This I possess through the lindness of Dr. Areschoug, who informs me that it is mercly to be considered as a prodromus to a more complete illustration of the species.

PLate IX. fig. 4. Polyporus sacer, nat. size.

10. Pol. xanthopus, Fr. = "Bol. pictus," König.

Ceylon. In Hcrb. Mus. Brit.

11. Pol. crenatus (König sub Boleto). Pilco brevissime stipitato tenui plano rigido subreniformi crenato-lobato rufo glabrescente zonato; hymenio pallide brunneo; poris minutissimis. "Boletus crenatus, Fl. Zeyl.," König in Herb. Mus. Brit.

Ceylon, König. Herb. Mus. Brit.

Pilci 2-3 inches brond, $1 \frac{1}{2}$ inch long, latcrally confluent, flat, thin, rigid, corky, shortly but distinctly stipitate, subreniform, regularly crenate with rounded lobes, bright redbrown, at first clothed with short, dull, tawny, velvety down, at length quite smooth and shining, repeatedly zoned; margin slightly turned back, obtuse. Ilymenium dull brown, uneven; pores round, so minute as to be quite indistinct to the naked cyc.

This species has a very peculiar habit. It resembles some states of Pol. xanthopus, which, like most central-stemmed Polypori, varies with a lateral or almost obsolete stem. It belongs with the two following to the section 4. Hornotini, Fr. Epicr.

12. Polyporus poccilus, n. s. Stipite brevi laterali; pileis subreniformibus rigidis lateraliter connatis brunneis sulgrlaucis subzonatis; hymenio ochracco; poris submagnis angulatis; dissepimentis tenuibus dentato-elongatis. "Boletus variegatus," König in Herb. Mus. 13rit.

Ilabitat uncertain. IIerb. Mus. Brit.

Forming patches 9 inches broad, $4 \frac{1}{4}$ inches long, consisting 
of latcrally connate pilci 3 or 4 inches broad. Pilei subreniform, slightly lobed, thin, very rigid, rugged behind, obscurely zoned, of a nearly uniform bistre-brown, with the clge however paler; smooth, but with a glaucous aspect, as if very minutely velvety; margin rather obtuse. Hymenium uncren, ochraccous; pores rather large, $\frac{1}{56}$ th of an inch broad; dissepiments thin toothed and elongated, often absorbed, so as to give the hymenium a Diedaloid aspect. Stem lateral, distinct, threc-quarters of an inch broad and long, pale like the margin of the pilcus, very obscurely velvety or pruinose.

'Ihis species must be arranged near Pol. fabelliformis, Kl., but I am unable to point ont any species with which it has a close affinity.

13. Pol. Königii, n.s. Pilco tenui rigido duro semiorbiculari subtiliter pruinoso-velutino glabrescente lineato-punctulato cervino zonis obscurioribus castancove; margine obtusiusculo ; poris parvis distinctis rotundis ; dissepimentis subintegris; contextu ferruginco pallidioribus. "Bol.spadliceus," Kön. Herb. Mus. Brit. "Bol. castaneus, Fl. Zcyl.," Kön. l. c. ut videtur provectior.

Ceylon, König. Herb. Mus. Brit.

Pilcus 2-3 inches broad, thin, very hard and rigid, semiorbicular, not undulated, marked with little linear pits, at first clothed with obscure velsety down, fawn-coloured with rufous zoncs. Stem very short, lateral, arising from an clongation of the vertex. Substance corky, ferruginous. Pores small, $\frac{1}{10} \bar{U}^{\text {th }}$ of an inch brond, distinct, round, with their borders even, paler than the flesh.

Boletus castaneus, Kön., is the same species of a more rufous tinge, with the stem morc evidently arising from the vertex, and fewer zones.

14. Pol. (Trametes) lactineus, n. s. Pileo sessili irregulari subcrasso duro rigido azono suberoso lacteo pruinoso-vclutino inæquali verruculoso; margine lobato; hymenio pallido; poris mediis rotundis dissepimentis crassis obtusis. "Boletus lacteus," König in IIerb. Mus. Brit.

König, Herb. Mus. Brit., without habitat.

Stemless. Pileus 7 inches brond, $3 \frac{1}{2}$ inches long, irregular, very hard and rigid, corky, rather thick, lobed, zonel iss, clothed with a uniform, very short, pruinose velvety down, uneven, with numerous little warts. II ymenium pallid, woodcolour; pores middle-sized, $\frac{1}{18}$ th of an inch brond, perfectly round, with thick obtuse dissepiments; substance of a pallid wood-colour.

15. P'ol. (Trametes) aureus, n. s. Pileo convexo dimidiat conchiformi sessili setis brevibus aureis vestito, zonato; $\mathrm{ma}_{\mathrm{r}-}$ 
ginc acutissimo; hymenio sub-brunneo ; poris longis pallidolignicoloribus mediis, acic irregulari denticulata.

Without habitat. Herb. MIus. Brit.

Pileus $2 \frac{1}{4}-3$ inches broad, $1 \frac{1}{2}$ inch long, conchiform, clothed with bright, tarny, straight, short, more or less distinct bristles, distinctly zoned with darker shades; margin extremely acute and rivid, very slightly wared, substance thin. Hymenium brownish; pores long, $\frac{1}{60}$ th of an inch broad, pallid woodcoloured, with a distinct trama, middle-sized, irregular ; edge slightly toothed; margin barren.

This species is evidently allied to Pol. suaveolens, but it is a much more beautiful plant, and differs greatly in its shortly setose pileus.

16. Pol. (Trametes) lacticolor, n. s. Pileo sessili semiorbiculari tenui suberoso-coriaceo subzonato carnco-fulro subpruinoso; contextu lignicolori, poris magnis rotundis acie obtusa. On decayed trunks of trees in woods.

Ceylon. König in IIerb. Mus. Brit.

Pileus 2 inches broad, $\frac{3}{4}$ inch long. Stemless, semiorbicular, thin, suberoso-coriaccous, very obscurely zoned, bright fawncoloured, slightly uneven, nodulose behind, clothed with extrenely obscure pruinose down. Substance wood-coloured, velvety ; edge thin, not lobed. Hymenium nearly cven; pores large, ${ }_{2}^{1}$ th of an inch broad, round, their disscpiments obtuse.

'T'he only species to which this appears to be allied is Pol. (Trametes) Beyrichii.

17. Polyp. dulius (Kön. sub Bolcto). Pileo fuligineo-fulvo, coffeato-pruinoso sessili basi cffusa semiorbiculari quandoque obliquo tenui duro rigido e sulcis radiantibus zonis decussatis rugoso; margine obtusiusculo ; contextu duro suberoso cervino ; poris mediis badiis irrfgularibus angulatis dissepimentis tenuibus sæpe confluentibus. "Bol. dubius, Fl. Zeyl.," Kön. in IYerb. Mus. Brit. On rotten wood in shady woods.

Ceylon, König. IIerb. Mus. Brit.

Pileus 3 inches broad, $1 \frac{1}{2}$ inch long, stemless, effused at the base, thin, very hard and rigid, semiorbicular, at length sometimes oblique, tawny brown, with a coffce-coloured bloom, rugged, with radiating furrows, which are crossed by many narrow zones; edge thin, but obtuse. Substance hard, corky, fawn-coloured; pores middle-sized, $\frac{1}{75}$ th of an inch broad, bay, irregular, angular; disscpiments rather thin, often confluent.

There is a Polyporus also from Ccylon in König's collection, which, though differing in some points, I refer to the same species. Some specimens are scarcely at all zoned, though others, especially when young, have many zones. 'The most striking difference consists in the absence of the strong radiating furrows, which give the state described as normal a re- 
markably wrinkled appearance. The pores and substance are alike, which are the points on which the greatest stress must be laid when difficulties occur. 'The pores however, especially in Hexayona, vary much in size, so that even these are not always decisive. This state appears to approach Pol. levissimus, Fr. E $\mathrm{E}_{\mathrm{p}}$. 'The colour in these specinens is far brighter.

18. Polyporus supinus, Fr. Bolelus resupinafus, Sitz.! Pr. p. 149. B. supinus, Fl. Occ. p. $1926=$ Pol. Valenzuclianus, Mont.!

'The plant of Montagne, of which a figure will appear in the history of Cuba, is preciscly that of Swartz. It was next to impossible without inspection of specimens to have ascertained their identity, the name of Swartz bcing altogether inapplicable, as the species is not resupinate. The name could have arisen only from an accidental inversion of the specimens obtained, which Swartz informs us were very few.

19. Polyporus zonalis, (Kön. sub Bol.) Subcrosus tenuis imbricato-multiplex sessilis lateraliter connatus rigidus; pileis semiorbicularibus rotundato-lobatis repetito-zonatis rugulosis pruinosis cervinis; zonis glabris subnitentibus rufis, margine acuto; poris minutissimis fuscescentibus. "Boletus :onalis, Fl. Zeyl.," König.

Ceylon, Könir. Herb. Mus. Brit.

Imbricated; pilci $1-2$ inches broad, $\frac{3}{5}-1$ inch long, sessile, lobed; lobes roundish or reniform, very hard and rigid, corky, contracted in drying, pruinose, fnim-coloured, with numerous rufous, smooth and rather shining furrow-lilie zones, with many of the interstices raised and forming sharp ridges; rugulose, in some specimens regularly decussated by minute raliating lines; edge very thin. Pores extremely minute, invisible to the naked eye, except a few whose orifices are oblique, brownish.

This species is allied to Pol. microporus, but differs from it in its regularly zoned brightly coloured pilcus and in its whole habit. It is perhaps more nearly allied to Polyporus micromegas, Mont., but the specimens of that species hitherto obtained arc so few and imperfect as to make it impossible to speak positively; better specimens may prove them scarcely at all allied. It is a very beautiful species.

l'bate X. fig. 5. Polyporus zonalis, nat. size.

20. Polyporus microporus, Fr. Pilco lignoso cffuso-reflexo rugroso glabro pallido intus albido, poris minimis acutis pallidis fuscescentibus. Boletus microporus, Swartz! Fl. Ind. Occ. p. 1925.

Jamaica, Swartz. Herb. Mus. Brit.

Pileus $2-3$ inches broad, widely effused behind ; margin, 
free, reflexed, waved, rugose, unequal, rigid, pallid, wood-coloured, zoned, very obscurely silky. Substance hard, pallid; margin very acute. Tubes very slender, stratose; orifices very minute*, nearly invisible to the naked cye, at first rood-coloured, then pale gilsous, at length, according to Fries, brown, angular or subrotund : dissepiments very thin, acute.

This species resenbles in many respects Polyporus Auberianus, Mont., as the foregoing does P'ol. micromegas, Mont. It is allied to Pol. ulmarius. Fries describes this species as zoneless, but the specimen in the British Muscum from Swartz is very evidently zoned. Polyporus Aubcrianus also is sometimes without zones or furrows; it differs so much in its large size and free development, that, from the inspection of a single specimen only of either species, it would be rash to give too decided opinion as to their identity.

P'Late X. fig. 6. Polyports microjorus, nat. size.

21. Polyporus scytinus, n. s. I'ileis basi cflusis lateraliter connatis limbo semiorbiculari coriacco flexili pallide badiofusco zonato spongioso-tomentoso; margine tenui acuto ; poris parvis subirregularibus, disscpimentis subobtusis pilco concoloribus. Cum. Phil. n. 2031.

l'hilippine Islands, Cuming. Herb. Mus. Brit.

Pilei 3 inches broad, $2 \frac{1}{2}$ long, stemless, effised at the base, horizontal, semiorbicular, scarcely lobed, laterally confluent, coriaccous, flexible, of a pallid bay-brown, repeatedly zoned, clothed with short spongy dorn; edge thin, acute, barren. Substance of the same colour as the pileus, soft, like that of Polyporus fomentarius. Pores short, small, $\frac{T}{T 0}$ th of an inch broad, rather irregular, their dissepiments rather obtusc.

Very much resembling Polyporus caperatus, but not so rigid and the pores are much larger. This species was not in the set described in the 'London Journal of Botany' from Sir W. J. Hooker's herbarium nor in my own.

'The specific name of $P$ 'ol. intylaccus, Berk., in ' Lond. Journal of Botany,' a species from the Philippine Islands, being jro-occupied, I ber to substitute for it that of Pol. cichoraceus.

22. Polyporus Floridenus, n. s. Pallide badius, pileis subflabellaribus lateraliter connatis tenuibus coriaceis zonatis pubescentibus ; zonis glabrescentibus ; poris parvis irregularibus subdentatis contextu gilvo-badio.

Eastern Florida, near Matanza. On dead trecs.

Val. Gardner, Esq. Herb. Mus. Brit.

Pilei forming patches 5 inches or more broad; the inclividunls of which they are formed being about 2 inches broad, 11 long, latcrally connate, subfabelliform, very thin, coria-

* In the figure they are too strongly expressed. 
ceous, repeatedly zoned, clothed with very short dense pubescence, which in the darker zones, which are comparatively smooth, is arranged in lines; margin very slightly lobed, extremely thin and acutc; substance corky. Pores small, $\frac{1}{10} \bar{t}^{\text {th }}$ of an inch broad, irregular; dissepiments shortly dentate, clongated; margin barren, obscurely tomentose. Colour of the whole plant, including the substance, of a more or less pallid bay, like that of Thelephora laciniata.

The nearest ally of this species is Pol. scytinus, described in the present memoir. It is a smaller plant of a very different form, not to mention other points of distinction.

23. P'ol. zcylanicus, n. s. Pilco valde tenui lobato coriaceo gilvo-cervino lineis pliciformibus fasciculato-fibrosis exasperato; postice scabroso; poris submagnis disscpimentis tenuibus dentatis elongatisque. " Bol.radiatus, Fl. Zeyl.," König in IIcrb. Mus. Brit.

Ccylon, König. Herb. Mus. Brit.

Pilcus 2 inches long, $2 \frac{1}{2}$ inches broad, stemless, very thin, lobed, coriaceous, marked with radiating fold-like lines, which bear branched fascicles of fibres, and towards the base are rough with isidiiform processes, reddish fawn-colour with a satiny lustre. Substance fawn-colourcd, sillyy. Pores rather large, $\frac{1}{3}$ th of an inch broad, their edge toothed and elongated ; margin extremely thin and acute, barren. Resembling Pol. sericco-hirsutus, K1. (Hexagona scricea, Fr.), with somewhat of the aspect of Hexagona polygramma, Montagne.

24. Pol.nigro-cinctus, n. s. Imbricatus rigidus; pileo fragili villo strigoso cincreo vestito ; margine brumneo; poris parvis subcinereis. "Boletus frayilis," Könin in Ilerb. Mus. Brit.

Ceylon and elsewhere, König. Herb. Mus. Brit.

On trunks of tress, but not common.

Stemless, imbricated, with the habit of a small Stereum. Pileus one inch broad, half an inch long, thin, rigid, clothed with cincreous, rigid, matted, strigose hairs or bristles, with one or two zones ; margin slightly; lobed, striate, deep brown, extremely acutc, forming occasionally a crest-like ridge. Pores small, $\frac{1}{30}$ th of an inch broad; dissepiments rigil, cinercous, wookl-coloured.

'Two forms or rather stales of this species occur: one, which scems to be the more normal form, described above; the other from Ceylon, on charred wood, is morc regular and occasionally almost smooth, with the pores irregular and the dissepiments obtuse.

I am unable to point out any species to which it is nearly allicd, except perhaps $P$. cingulatus.

25. Pol. yalbanalus, n. s. Pilco subtenui plano suberoso obsolete zonato luteo-relutino setis longioribus passim im- 
mixtis; hymenio pallide flavo; poris parvis subrotundis dissepimentorum acie xquali. "Bol. lutescens," König in Herb. Nus. Brit.

IIabitat unknown. IIerb. Mus. Brit.

Pilcus sessilc, plane, $2 \frac{1}{2}$ inches broad; $1 \frac{1}{2}$ inch long, rounded, rather thin, corky, obsoletely zoned, clothed with velvety down, towards the middle adorned with zoncs of longer and stiffer bristles; margin obtuse, even; disc slightly waved. Hymenium pallid yellow; pores small, $\frac{1}{y \bar{u}}$ th of an inch broad, subrotund; border of dissepiments even.

Allied to Pol. hirsutus, but, as it appears to me, very distinct.

26. Polyporus Meñiezii, n. s. Pileo cuneato antice rotundato tenui coriaceo flexili obsolcte zonato lignicolori glabro; poris mediis dissepimentis tenuibus.

Sumatra, Menzies. Herb. Mus. Brit. on charred wood.

Pileus $1 \frac{1}{6}$ of an inch long, $1 \frac{1}{1}$ broad, in front cuneiform, arising from a minute round disc, laterally confluent, very thin and flexible, dull wood-coloured, obzoletely zoned, smooth, minutely radiato-striate in front, where it is rounded and scarcely lobed. Pores middle-sized, $\frac{1}{6}$ th of an inch brond, angular; dissepiments thin, edge nearly even. IIymenium slightly concave, surrounded by a rather broad barren border.

In form resembling Pol. sector, but differing remarkably in the size of the pores.

27. Polyporus membranaceus, Fr. Flabellato-multifidus lobatus plicatus pallidus sericco-striatus grlabrescens subnitidus multizonatus membranaceus tenuissinus; poris parvis curtis ; dissepimentis tenuibus demum laceris difformibus. Boletus membranaceus, Swartz! Prodr. p. 148; Fl. Ind. Occ. p. 1922.

Jamaica, Swartz. IIerb. Mus. Brit.

Flabellato-multifid, repeatedly lobed and plicate; lobes rounded, sublaciniate, very thin and membranaceous, scriceostriate, pallid, at length nearly smooth and shining, adorned with many zones, especially towards the margin, where they are close and regular. Pores ochraccous, small, $\frac{1}{10} \overline{0}$ th of an inch in diametcr, at length irrergular; dissepiments very thin, toothed and elongated.

I'Late X. fig. 7. a, Polyporas membranaceus, mat. size; $b$, portion of the hyinenium magnified.

28. Decdalea incequalilis, n. s. Pilco tenui suberoso-coriaceo subrigido multizonato, subundulato, glaberrimo lignicolori ; poris magnis plus minus elongratis, dissepimentis tenuibus acic acuta siepe lacera.

Ceylon, König. Herb. Mus. Brit.

Pileus oblique, sessile, $2 \frac{1}{4}$ inches long, and about as much broad, thin, rather rigid, corky, wood-coloured, quite smooth, 
repeatedly but not strongly zoned, slightly undulated and uneven; edge very thin and acute; substance of the colour and consistence of cork. Pores large, $\frac{1}{16}$ th- $\frac{1}{20}$ th of an inch broad ; disscpiments rather thin, acute, often torn and elongated behind, very shallow towards the margin, wood-colourcd like the pileus. The pileus does not shine, but though of a different colour has somewhat the aspect of that of IIexagonu tenuis. It resembles Dadalea tenuis, but is much more zoned, and the disscpiments are much thinner.

29. Hlexagona IVightiti (sphalmate Wrightii), Fr. Polyporus (Scenidlium) l',ightii, Kl, in Linn. vii. p. 200. Boletus Favus, L: Ins. Ind. Or., A. Dalrymple, Lisq. Herb. Mus. Brit.

Hexayona temuis is marked in the Linnean Herbarium Bolctus Favus, but not by Linneus, with whose description it does not correspond. The name is eridently not authentic.

30. Hexagone Königii, n. s. Pileo suberoso-coriaceo subreniformi subazono plano fibroso-setoso gilvo-badio; alveolis irregularibus amplis, dissepimentis clongatis subflaccidis setulosis.

Ceylon, König. IIerb. Mus. Brit.

Pileus 3 inches broad, $2 \frac{1}{4}$ long, thin, suberoso-coriaceous, subreniform, from a distinct but not stipitiform vertex, very obscurely zoned, deep red-brown, rugose, clothed with scattered branched rigid bristles, which at length fill off, leaving a raised line; substance ferruginous, velvety, like that of $p$ pol. fomentarius; alveoli large, nearly a line broad, very irregular; dissepiments thick, not rigid, elongated and toothecl, paler than the pileus, deep setuluse within.

This species is very nearly allicd to Hexagona Wightii, differing principally in the irregular elongated pores with flaccid, not rigid, dissepiments. The pores are so little hexagonal, that were it not for the very evident affinity, it might be placed in the genus Declalea.

31. IIexagona papyracea, n. s. I'ileo sessili semi-orbiculari, papyraceo, tenui, flexili, subtiliter velutino glabrescente crebri-zonato sanguineo-lignicolorique variegato; hymenio cervino; poris hexagonis regularibus mediis.

Herb. Mus. Brit. Iab. unknown.

pileus 9 inches broad, 5 inches long, sessile, semiorbicular, thin as paper and very flexible, marked with little raised radiating striae, repeatedly zoned with intermediate finer lines, variegated with sanguineous and ligncous shades, at first clothed with extremely fine olive-brown velvety down, like a coat of some Cladosporium ; edge cxtremely acute, of a more tawny tinge than the rest of the pilens; substance bright fawn-coloured, silky. Hymenium fawn-colcured; pores hex- 
argonal, $\frac{1}{60}$ th of an inch broad, cxtremely regular, marked on the basal side with concentric lines.

This very fine and striking species, of which unfortunately the locality is unknown, resembles most a species gathered by Schomburgk in Brazil, which I have communicated to Dr. Niontagne under the name of H. variegata, but which is considered by him as a non-sctose state of his Hexagona aculeata. Both are entircly destitute of the strong fascicles of hairs or bristles which are so remarkable in many species.

32. Hexayona sericea, Fr. Polyporus sericeo-hir-sutus, Kl.! in Linn. viii. p. 483. = Boletus villosus, Swartz! Prodr. p. 149; Fl. Ind. Occ. p. 1933.

The specimen in the Herbarium of the British Museum, marked by Swartz himself, is exactly the plant of Klotzsch. Fries howerer kecps the two distinct.

33. Hexagona tenuis, Fr. = "Bol. Psidii," Kön. in Herb. Mus. Brit.

This species varies much in the size of the pores. It is probalble that the number of species in this genus, though small, will hereafter be considerably recluced.

34. IIydnum flavum, n. s. Pileo sessili suborbiculari convexo tenui "pallide flaro" glaberrimo, hymenio pallido, aculeis brevissimis granulato-denticulatis. Peziza flava, Swtz.! Prod. p. 150; Fl. Ind. Occ. p. 1933.

On wood. Jamaica, Swartz! IIerb. Mus. IBrit.

Pileus $1 \frac{1}{2}$ inch long, nearly as much broad, suborbicular, but involute when dry, stemless, attached by the apex, thin, perfectly smonth and shining, of a bright orange-yellow when dry, darker at the margin, which is very acute. Hymenium pale; aculei very short, subcylindrical, with a fer acute granuliform processes at the apex.

It gives me much pleasure to be able toclear up a very doubtful species, which proves to be a very beautiful and interesting Hydnum. The aculei are so minute as almost to justify the association of the species with Grandinia. The genera of Ilymenomycetes at present are however so unsettled, that I prefer placing it in Hydnum. Swartz described the smooth outer surface of the pilcus as the hymenium; it contains however no asci, and is most certainly the upper surface, as will be seen by the figures.

PLat: X. frg. 8, a, Iydhum flavum, nat. size; $b$, section magnificd; $c$, a portion of the substauce of the pileus highly magnified.

35. Iyylnum discolor, Fr. Pilco sessili carnoso convexo levi glabro pallido, nculeis cylindricis obtusis subulatisve aequalibus ferrugincis. Hydmum ayaricoidcs, Swartz! Prodr. p. 149 ; I.l. Ind. Occ. p. 1927. 
On.wood. Jamaica, Swartz. IIcrb. Mus. Irit.

Stemless, $1 \frac{1}{2}$ inch or more across, convex, attenuated behind, scmi-orbicular, rather thick, pale, with a few indistinct zoncs, fleshy and brittle when fresh, when old tough and dark like the prickles; smooth, except towards the very slightly undulated margin, where it is scabrous; substance pale; prickles 2-3 lines long, crowded, simple, diaphanous, ferruginous brown, cylindrical, slender, obtuse, or acute.

In the dry state the pileus is nearly as dark as the prickles, but the substance remains pale.

Hydnum sericeum, Swtz.! (Thelephora sericea, Fl. Occ. p. 1028) belongs to the genus Dichonema, or rather Diclyonema, for the latter secms to be a more perfect state of the former.

P'Late X. fig. 9. d, IIJdnum discolor, nat. size; $e$, section near the margin, magnificd.

36. Thelephora setosa, Swtz. Imbricata c basi effusa rcflexa ferruginco-fusca fibris ramosis vestita subzonatia; hymenio inacquabili granulato sctuloso. Hydnum vesupinalum, Swartz! Prodr. p. 149. Thelephora sctosa, Fl. Ind. Occ. p. 1029.

Jamaica, Swartz. Herb. Mus. Brit.

Pilci stemless, imbricated, 1 inch or more broad, 3 inch long; base effused, margin reflected, of a dull fervuginous brown, obscurely zoned, clothed with coarse branclied fibres somewhat after the manner of Pol.hydnoideus, $t$ of an inch long, which compose almost the whole substance of the pileus. Hymenium granulated, of the same colour as the pileus, with very minute scattered bristles.

An extremely curious and well-marked species, being to Thelcphora what Corticium crinitum is to Corticium.

PLATE XI. fig. 10. Thelephora setosa, nat, size.

37. Stercum pusillum, n. s, Cartilaginco-coriaccum, pilco flabcllari nitide umbrino-rufo azono scricco-striato glabro; margine acutissimo tenui lobato; stipite curto sublaterali crecto, hymenio pallido lavi glabro. "Clavaria pezizaformis, Fl. Zeyl.," König in Herb. MIus. Brit.

Ccylon, König. Herb. Mus. Brit.

Stem $f$ of an inch high, lateral but vertical, giving off a flabelliform pilcus not $\frac{1}{9}$ an inch long and broad, slightly lobed, laterally connate, rather rigid, smooth but sericco-striate, of a bright burnt umber, not zoned; edge very thin, divided into two or three obtuse lobes. Hymenium pale, smooth, quite frec from bristles. Allicd to Stereum elegans. 
35. Stereum reniforme, Fr. Ep. p. 546. "Helvella nova." Herb. Mus. Brit.

Ierb. Mus. Brit. Vithout habitat. Probably from Swartz.

Stem more than an inch high, about one line thick, lateral, attenuated upwards, downy, ferruginous, sprinkled, as is the whole plant, with short bright brown seta. Pileus I inch broad, about $\frac{1}{2}$ an inch long, thin and flexible, but coriaceous, reniform, slightly lobed, obscurcly zoned, marked with very fine radiating raised lines of a golden cinnamon-brown. Edge very thin and acute, slightly waved. Hymenium even, of the same colour as the pileus, setulose.

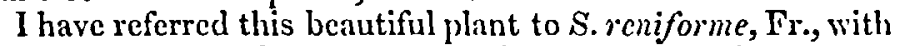
which it very closely arrees, differing chiefly, as far as may be judged from the short diagnosis, in its more golden huc. The colour and substance are exactly those of some of the bright-coloured cxotic forms of Stereum rubiginosum.

Prate Xl. fig. 11. Stereum roniforme, nat. size.

39. Stereum atratum, Fr. Umbonato-sessile, pileo tenui rigido lrvi fusco nigro-fasciato subtiliter olivacco-relutino demum glabro versus marginem undulatum pallidiori; hymenio demum rimoso glabro atro. Helvella atrata, Swartz! Prod. p. 149. Thelephora atrata, Fl. Ind. Occ. p. 1933.

Jamaica, Swartz. Herb. Mus. Brit.

Pilei $1 \frac{1}{1}$ inch long, 1 inch broad, laterally connate, rotundato-cuneiform, slightly lobed or undulated, thin but very rigid, clothed at first with minute subolivaceous velvety down, dark brown, with narrow black concentric bands; substance cervino-ferruginous. Hymenium dark brown, rather scabrous but not bristly, concentrically cracked.

The specimen which I have had an opportunity of inspecting is old and in a bad state, but it presents one or two claracters not noticed by Fries.

Peate XI. fig. 12. Stereum alratum, nat. size; $n$, uppor side; $b$, hymenium.

40. Stereum versicolor, Fr. Umbonato-sessile submembranaceum; pilco subtiliter villoso ; villis radiantibus ; zonis margineque glabrescentibus fuscis variegato; hymenio lavi glabro pallido. Helvella versicolor, Swartz! Prod. p. 149. Thelephora versicolor, Fl. Ind. Occ. p. 1934.

Jamaica, Swartz! Herb. Mus. Brit.

Pilei 1 inch long, laterally connate, umbonato-sessile, of a tawny ligneous hue, varicgated with narrow concentric bands of greater or less intensity, coriaceo-membranaccous, lobed and undulated, clothed with silky villous fascicles, all lying in a radiating direction. Ilymenium pale ochre, very smooth. 
The distinguishing character of this clegant species appears to depend on the peculiar nature of the villous coat. Stereum lobatum is also characterized by Fries as villous, but in one of the forms, that published by Klotzsch in the 'Linnaa,' the pubescence is thickly matted, none of the individual hairs projecting beyond the main mass; while in the other, though the hairs are more distinct, there is nothing like the radiating arrangement which is visible in Swartz's specimens. The habit too is different. S. versicolor is a much smaller species. The subject being really one of some difficulty, a figure from authentic specimens cannot fail to be acceptable.

Pzataxi. fig. 13. a a, Stereun ecrsicolor, nat. size; $b$, portion magnified.

41. Guepinia palmiceps, n.s. Stipite compresso subtiliter velutino cum pilco palmato-lubato confluente; hymenio subplicato rufo. "Clav. muscoides, Fl. Zcyl."

Ceylon. IIerb. Mus. Brit., König.

From $\frac{1}{2}$ to $\frac{5}{4}$ of an inch high ; stem compressed, dark at the base, fawn-coloured, clothed, as is the pileus, with very minute velvety down, divided into two or more branches, which expand above into a somewhat spathulate pileus, with about six nearly equal, sometimes emarginate lobes ; margin slightly thickened, subreflexed. Hymenium very obscurcly folded, deep rufous.

Plate XII. fig. 14. a a, \& 15 b, left sile, Gucpinia palmicrps, nat. size.

42. Guepinia fissa, n. s. Stipite compresso subtiliter velutino; pileo fisso, lobis demum linearibus; hymenio luteo. "Clavaria lutea, Malacca and Siam."

Könir. Herb. Mus. Brit.

Nearly of the same size as the foregoing; pileus irregularly split into more or less linear lobes, which are themselves slightly lobed at the side. Hymenium ochraceous yellow.

Very much resembling the last, but differing in the less regular mode of division and in the paler hymenium. The clothing of the pileus and of the stem is the same in both species.

Both the species have a strong resemblance to Guepinia spathularia ; but after an inspection of abundant specimens of the North American species, which has the hymenium very much more strongly plicate, I am inclined to consider them as distinct.

PLATE XII. fig. 15. b, the right hand figure, Guepinia fissa, nat. size.

43. Clararia compressa, n. s. Pallida, mycelio fibrilloso niveo, stipite compresso, furcato; ramis paucissimis tenuibus cylindricis; apicibus ncutis. 
Jamaica. Ierb. Mus. Brit, On rotten wood.

Plant $1 \frac{1}{4}$ inch high ; mycclium whitc, branched, fibrillose, penetrating into the wood; stem compressed, $1 \frac{1}{2}$ line thick, springing from a broader base, divided above into four principial, rather flexuous, slender cylindrical branches connected at the base, and forked once or twice only; tips very acute. The whole plant is of a pallid ochraceous hue.

This species is evidently allicd to Clavaria crispula and byssiseda. It agrees more with our common forms of Clavaria than those which are peculiar to the 'l'ropics.

Plate XII. fig. 10. Clavaria compressa, nat, size.

44. Exidla rufa, n. s. Cupularis sublateralis intus nigra; extus setis brevibus fasciculatis rufis vestita.

Herb. Mus. Brit. Ceylon, König.

Two or three inches or more across, cup-shaped, generally attached laterally; very hard and rigid when dry ; slightity plicate at the base, clothed with short, fasciculatc, hispid, bright sienma-brown bristles. IIymenium smooth, not much wrinkled, dark brown, inclining to black. Tery distinct from every species $I$ have seen in its bright red-brown bristles. The nearest species is Exidia polytricha, Mont.

Plate XII. fig. 17. Fixidia rufa, nat. size.

45. Exidia fusco-succinea, Mont.

Jamaica, Mr. Poore. Herb. Mus. Brit.

'This is perhaps Pez, nigra, Swartz, which is certainly an Exidlia.

46. Spheria thyrsus, n. s. Suberosa, simplex, clavula obovata acuminata pallida, peritheciis sursum spectantibus magnis, ostiolis subclongatis obtusis nigris ; stipite clongato cylindrico deorsum longissime radicato. "Clathrus acuminatus," Roxb.

In the Botanic Garden, Calcutta. IIerb. MIus. Brit.

Whole plant nearly six inches high, rooting decply into the soil ; root flexuous, attenuated downwards; stem cylindrical, nearly equal, black, slightly wrinkled, white within, surmounted by the palc fawn-coloured, acuminate, obovate head, which is rough from the protrusion of the black ostiola, which all point upwards, so as to give it the appearance of a little fir-conc. Perithecia obovate, with a short neck. Asci linear, obtuse, containing eight subcymbiform dark brown sporidin, which are furnished on one side with a gelatinous coat projecting beyond the apices.

This spccics, of which I understand from Dr. Brown much larger specimens occur, is allied to Sph. pelunculata, Dicks. 
Like that species, the sporidia have a gelatinous coat, but surrounding only one side, like an arillus. This is sometimes contracted at the sides, so that a portion of it projects at either end of the sporidium, forming a little transparent appendage. It is probable that in an carlicr stage of growth the coat entirely surrounded the sporidium.

PLate XII. fig. 18. Spharia thyrsus, nat. size; $a$, ostiola and perithecia; $b$, ascus with its sporidia; $c$, sporidium with its gelatinous appendage. All more or less magnified.

47. Sphceria ianthino-velutina, Mont.

Clavaria fusca, Swartz! Prod., is referable to this or some closely allied species. The specimens are very imperfect, and without fruit.

48. Sphceria escharoidea, n. s. Suberosa simplex clavula cylindrica apiculata ex ostiolis conicis prominulis scabra, pallida; stipite elongato, cylindrico, radicato. "Clavaria pistillaris? nembrana cscharoidea tecta. Fl. Zeyl." König in Nerb. Mus. Brit.

Ccylon, Dr. König. Herb. Mus. Brit.

Whole plant about 3 inches high, rooting decply; root nearly cqual, flexuous, uneven, nodulose, about $\frac{3}{5}$ of a line thick ; stem 1 inch high, cylindrical, cqual, slightly thickened at the base, about $\frac{1}{3}$ rd of a line thick, black, washed with a dull white coat, minutely striate or wrinkled, quite smooth ; head cylindrical, equal, nearly an inch high, obtuse at either end, tipped with a sharp apiculus, pallid, rough, with the conical prominent ostiola of the small perithecia. Sporidia not yet developed.

A very distinct species, which can scarcely be confounded with any described by authors. The head resembles the spike of a Peperomia.

Puate XII. fig. 10. Spheria escharoidea, nat. size.

49. Sph. œdipus, Mont. Jamaica. Herb. Mus. Brit.

XLVI.-Observations on a new Group, Gemus and Subgenus, of Freshwater Conferva, with descriptions of Specics mostly new. By Arthur Hill Hassall, Esq., M.R.C.S.L. Corresponding Member of the Dublin Natural IIistory Society.

$$
\text { [Conchuded from p. 311.]. }
$$

IT now becomes necessary that I should make a few bricf remarks upon the classifications of the younger Agardh and M. J. Decaisne, but only in so far as these have reference to the group Vesiculasperma.

Ann.\&Mag. N. Hist. Vol.x. Suppl. 